Rapp. Grønlands geol. Unders. 66, 21-31 (1974)

\title{
A ZIRCON AGE FROM GABBRO-ANORTHOSITE INCLUSIONS IN THE GNEISSES OF THE ANGMAGSSALIK AREA, SOUTH-EAST GREENLAND
}

\author{
Paul D. Nunes, Rudolf H. Steiger and David Bridgwater
}

\begin{abstract}
Age determinations were made on 3 zircon fractions extracted from gabbroanorthosite inclusions which occur as tectonically dislocated pods in quartzofeldspathic gneisses on the eastern end of Kitak island, South-East Greenland (fig. 5). The anorthosites were selected for study because they are derived from a lithologically distinctive suite of rocks found over a large part of the Archaean craton of the North Atlantic area (Bridgwater et al., 1973b). While there is no evidence that all the anorthosites of this type are contemporaneous their formation appears to require special conditions in the crust and they are thus likely to be a useful stratigraphic tool. Furthermore the coarse-grained refractory nature of these rocks means that they retain their lithological identity during later tectonic, anatactic and metasomatic events to a far greater degree than the quartzofeldspathic, semipelitic and amphibolitic units making up the major part of the gneiss complex in which the anorthosites occur.
\end{abstract}

\section{Regional setting and character of the anorthosite suite}

The anorthositic rocks form between one and five percent of the Archaean gneiss complex of Greenland. They occur either as deformed and metamorphosed layered igneous bodies concordant with the regional foliation in the surrounding gneisses, or as trains of inclusions surrounded by a quartzo-feldspathic matrix. Individual layers reach five kilometres in thickness and may be traceable for tens or even hundreds of kilometres along their length. Primary igneous features such as cumulate textures or graded igneous layering are commonly preserved even in dislocated and isolated pods and may be used to determine the original stratigraphic top of individual units. Among the various units reported a distinctive 


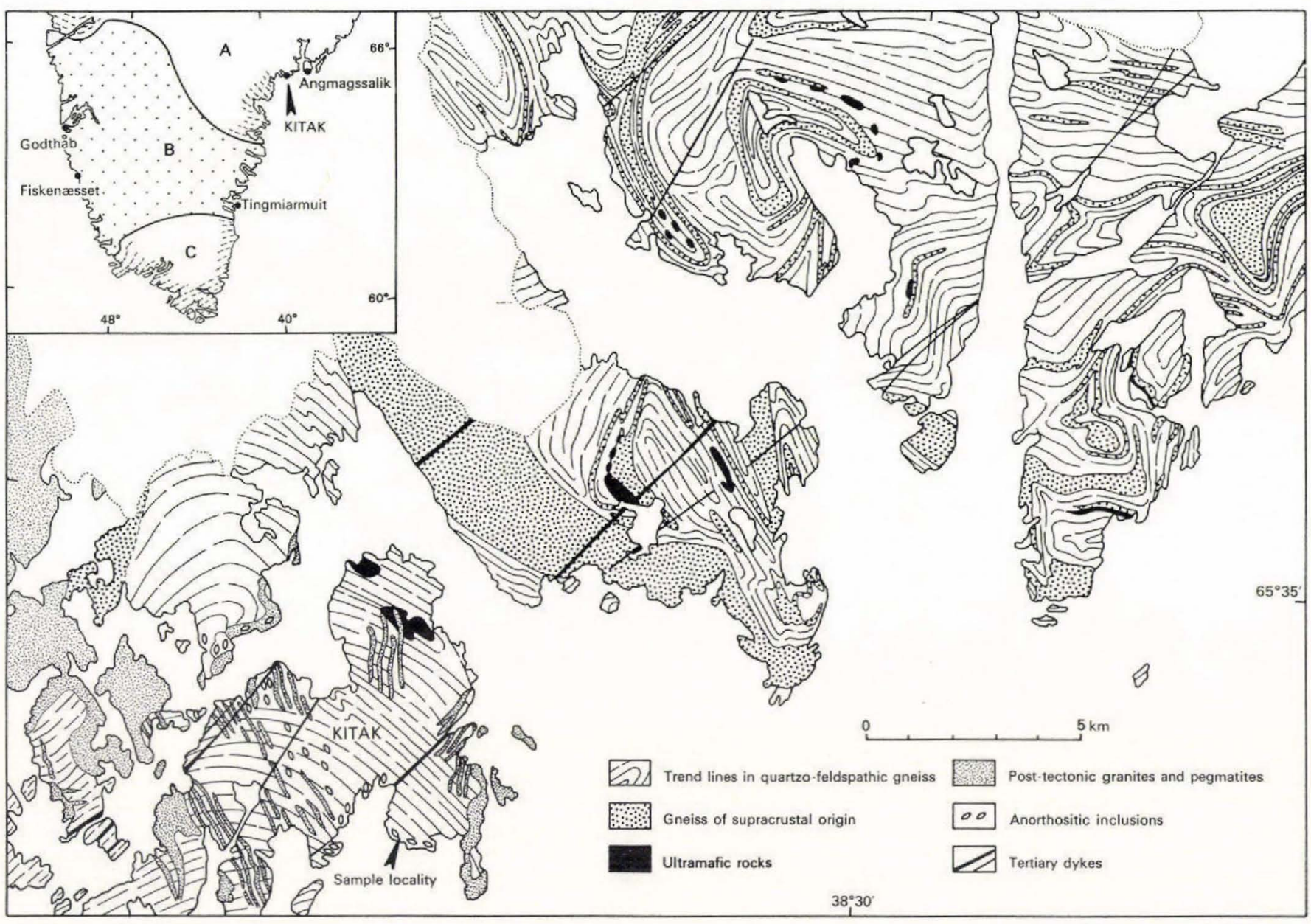

Fig. 5. Geological sketch map of the area around the island Kitak, South-East Greenland. Drawn from field maps and photo-geological interpretation by Bridgwater and Gormsen in 1968, slightly modified to include corrections by Palmer (1971). Inset: A Nagssugtoqidian mobile belt. B Archaean block unmodified by Proterozoic tectonism. C Ketilidian (Proterozoic) mobile belt. 
gabbro-anorthositic rock containing rounded bytownite phenocrysts up to 10-20 $\mathrm{cm}$ in diameter in a matrix of hypersthene and hornblende is frequently encountered in the best preserved parts of the anorthosite complexes.

The original conditions under which the anorthosites were emplaced is unknown and has been subject to much speculation. Most of the contacts between anorthosite and their original country rocks have been destroyed by tectonism either at the time of emplacement or later. Detailed mineralogical and chemical studies by Herd (1972 and in Windley et al., 1973) suggest that these bodies initially crystallised at a pressure of at least 5-7 kb implying that they were emplaced at depth. Myers (1973) gives evidence that the upper anorthositic part of the intrusions remained mobile after crystallisation and first deformation of the lower gabbroic units. This suggests emplacement in a tectonically active environment.

Most of the anorthosites showing well preserved primary igneous features are concentrated in the area between Godthåbsfjord and Frederikshåbs Isblink on the west coast of Greenland. Outside this area the anorthosites are severely brecciated by later tectonic and magmatic events and are generally preserved as isolated pods. These anorthositic pods often have primary igneous textures but in thin section are found to consist of granular aggregates of plagioclase, hornblende and diopside together with secondary break-down products such as epidote, quartz, chlorite and sericite distributed in patches of light and dark material. The composition of the plagioclases in these crystal aggregates varies from area to area depending on the local metamorphic conditions rather than reflecting the original composition of the bodies from which they were derived. Bondesen \& Henriksen (1965) and Henriksen (pers. comm. 1973) report that in the north-west of the Ivigtut region plagioclases from the gabbro-anorthosite pods are generally calcic labradorite or bytownite with sericitised centres, while farther south-west where the Archaean rocks have been overprinted by Ketilidian (Proterozoic) amphibolite facies metamorphism they range between andesine and sodic labradorite as fresh saccharoidal granular masses. A similar variation can be seen within single anorthosite pods which have been affected by deformation under low to medium grade metamorphic conditions. The relatively undeformed pods commonly contain aggregates of sericitised bytownite or calcic labradorite while the highly deformed margins contain clear aggregates of sodic andesine or oligoclase.

The age of the anorthosites on the west coast is only known within wide limits. In the Godthåbsfjord area they were intruded and brecciated by early members of the Nûk gneiss suite other members of which have yielded a $\mathrm{Rb} / \mathrm{Sr}$ wholerock isochron age of 3040 m.y. (Pankhurst et al., 1973). They are not intruded by the Amitsoq gneisses which have yielded a $\mathrm{Rb} / \mathrm{Sr}$ whole-rock isochron age of approximately 3750 m.y. (Moorbath et al., 1972). Outside the Godthåbsfjord area they are cut and brecciated by the possible equivalents of the Nûk gneisses and are affected by regional granulite facies metamorphism dated at approximately 2800 m.y. $(\mathrm{Pb} / \mathrm{Pb}$ whole-rock isochron on gneisses and anorthosites from three 
widely separated parts of tle Archaean complex (Black et al., 1973)). No anorthosites have been reported as younger than the 2800 m.y. granulite facies event on the west coast of Greenland. Correlation between east and west coasts of Greenland is so far tentative and isotopic control is limited to determinations of the younger events. Granulite facies metamorphism affected some of the gneisses at a comparatively late stage in their development on the east coast and a single $\mathrm{U} / \mathrm{Pb}$ zircon diffusion age of 2808 m.y. (Gulson \& Krogh, 1972) from a high grade supracrustal rock is thought to give the age of this event. The only other guide to correlation across the $250-500 \mathrm{~km}$ wide Inland Ice is given by the similarity in rock types and sequence of events recorded from the two areas (Bridgwater et al., 1973a).

\section{Regional geological setting of the island Kitak}

Kitak island and the area immediately to the east (fig. 5) consist of quartzofeldspathic gneisses, metamorphosed supracrustal rocks, anorthosite pods and some ultrabasic bodies all of which form part of the Archaean gneiss complex. In this area the Archaean gneisses were intruded by several generations of late Archaean - early Proterozoic basic dykes and were tectonically reworked in zones of high deformation during the formation of the Nagssugtoqidian mobile belt some time before 1800 m.y. ago (Bridgwater et al., 1973a; Escher et al. in press). The shearing movements which gave rise to the zones of high deformation and complex outcrop patterns occurred several times in the late Archaean - early Proterozoic history of the Nagssugtoqidian mobile belt. Kitak island was affected by an early phase of this deformation which imparted a strong sub-horizontal schistosity to the gneisses before the injection of the late Archaean - early Proterozoic dykes. Field investigations currently in progress on the west coast suggest that the early Nagssugtoqidian movements occurred before 2500 m.y. ago. The injection of basic dykes was followed by further deformation and by the emplacement of a late to post-tectonic suite of granodiorites, adamellites and granites which sent large swarms of pegmatite into the surrounding gneisses. The young granitic intrusives form large areas to the north-west of Kitak island. Local outcrops on the east coast of the island may indicate that the whole of the island is a roof zone to a large granitic body lying at a comparatively shallow depth below the present erosion surface. $\mathrm{Rb} / \mathrm{Sr}$ mineral ages from the granitic suite (Wager \& Hamilton, 1964) suggest that these bodies were emplaced at some time before 1800 m.y. ago.

\section{Detailed geology of the Kitak island locality}

Zircons used in this study were separated from gabbro-anorthosite pods which are found as discrete masses up to $1-2 \mathrm{~m}$ in diameter surrounded by a matrix 
of highly deformed quartzo-feldspathic gneiss and brecciated anorthosite fragments.

To the east of the anorthosite sampling locality the quartzo-feldspathic gneisses contain large amounts of amphibolitic basic material as trains of inclusions and schlieren in a highly contaminated matrix. Major bodies of ultrabasic material also occur as inclusions within the quartzo-feldspathic gneisses. These basic and ultrabasic inclusions are thought to be remnants of a supracrustal suite of lavas and metasediments represented to the north-east of Kitak by major units of biotite-garnet-kyanite gneiss interlayered with diopside-rich calc-silicate layers and ultrabasic horizons. All the major contacts between the Archaean rocks exposed on Kitak island are highly deformed and conformable. By analogy with other parts of the Archaean gneiss complex it is suggested that the anorthosites were originally emplaced as a conformable igneous suite either along an original contact between supracrustal rocks and older gneisses or within a supracrustal succession part of which has been lost. The quartzo-feldspathic gneisses enclosing the anorthosites and the adjacent amphibolitic rocks as inclusions are thought to be derived from a granite suite emplaced as a sub-concordant intrusion along the earlier anorthosite-supracrustal contact. The granites migmatised and broke up the anorthosites and the adjacent layers of amphibolite in the supracrustal rocks. Later deformation further broke up the anorthosites and imparted a marked foliation on the surrounding gneisses.

\section{Petrology of the anorthosite inclusions}

The inclusions are lensoid, with moderately well preserved original igneous textures in the centres of the lenses and more highly deformed margins. The matrix surrounding the inclusions contains separated plagioclase aggregates derived from earlier megacrysts set in a finer-grained groundmass of plagioclase fragments, epidote, hornblende, biotite and chlorite veined by contaminated more granitic material. The petrology of the inclusions varies markedly from margin to centre. The highly recrystallised margins are made up of aggregates of clear sodic oligoclase crystals, calcite, sericite, quartz, zoisite and chlorite. Microcline is seen in some sections. The centres contain larger grains of plagioclase commonly with an andesine or labradorite margin to a sericitised centre. Rare relics of bytownitic feldspar are found within the sericitised centres of some plagioclases. Mafic minerals show a similar variation from margin to centre of the anorthosite inclusions: biotite, chlorite and epidote are characteristic of the highly deformed margins. Hornblende is the main mafic mineral in the less deformed centres.

Zircons seen in thin sections are highly variable in shape and size. Occasional rounded zircons up to $0.15 \mathrm{~mm}$ have been found enclosed by plagioclase. Much smaller elongate zircon crystals are found within biotite crystals. 


\section{Analytical results}

About $220 \mathrm{~kg}$ of gabbro-anorthosite were received in the Zürich laboratory, some of the larger blocks weighing between 10 and $40 \mathrm{~kg}$. The blocks were composed mainly of medium-grained $(\Phi 3 \mathrm{~mm})$ anorthosite, cut by dark contorted bands or schlieren of biotite-hornblende schist or an occasional pegmatite vein. We carefully removed both the schistose and the pegmatitic components from $160 \mathrm{~kg}$ of original material before crushing. The resulting $100 \mathrm{~kg}$ of selected anorthosite yielded about $1.5 \mathrm{~g}$ of pure zircon. By sieving we subdivided the concentrate into three size fractions: $\mathrm{A}(<75 \mu), \mathrm{B}(>100 \mu)$ and $\mathrm{C}(>75<$ $100 \mu)$. Each size fraction was subsequently separated on a Frantz magnetic separator. The most magnetic fraction of $\mathrm{A}$, the least magnetic of $\mathrm{B}$ and an intermediate magnetic fraction of $\mathrm{C}$ were selected for analyses. The zircon populations consist of both round and euhedral grains with the majority of crystals exhibiting subhedral shape. All crystals have round ends. No overgrowths or outgrowths were observed. Both cloudy brownish and clear almost colourless crystals are present. The most concordant fraction B contained fewer cloudy grains $(25 \pm 6 \%)$ than fraction $\mathrm{C}(47 \pm 6 \%)$. The three fractions were analysed using the 'teflon bomb' technique (Krogh, 1973). The results are given in table 5 and plotted in fig. 6. The isotope ratios for fractions $B$ and $C$ were measured on a digitalised tandem mass-spectrometer, the resulting precision errors are much smaller than those of fraction $\mathrm{A}$ which was analysed on a $\mathrm{CH} 4$ mass spectrometer with a strip chart recorder. The solid straight line in fig. 6 is the best fit line passing through all three data points within their respective limits of error. It corresponds to an episodic $\mathrm{Pb}$ loss line (Wetherill, 1956) which intercepts concordia at $2698 \pm 6$ m.y. and $420 \div 110$ m.y. if the uranium isotopic composition and the decay con-

Table 5. Analytical data of three fractions of zircon from gabbro-anorthosite (GGU sample no. 99207) from South-East Greenland

\begin{tabular}{|c|c|c|c|c|c|c|c|c|c|c|}
\hline \multirow[b]{2}{*}{$\begin{array}{l}\text { frac- } \\
\text { tion }\end{array}$} & \multirow[b]{2}{*}{$\begin{array}{l}\text { mg. } \\
\text { sample }\end{array}$} & \multirow{2}{*}{$\begin{array}{c}U \\
\text { total } \\
\text { ppm }\end{array}$} & \multirow{2}{*}{$\begin{array}{c}\text { Pb } \\
\text { total } \\
\text { ppm }\end{array}$} & \multirow{2}{*}{$\begin{array}{l}{ }^{206} \mathrm{~Pb} / \\
{ }^{204} \mathrm{~Pb} \\
\text { (raw } \\
\text { date) }\end{array}$} & \multicolumn{3}{|c|}{$\begin{array}{l}\mathrm{Pb} \text { atomic abundance } \\
\text { relative to } 206 \mathrm{~Pb}=100\end{array}$} & \multicolumn{3}{|c|}{$\begin{array}{l}\text { Atomic ratios } \\
\text { (corrected for common } \mathrm{Pb} \text { ) }\end{array}$} \\
\hline & & & & & ${ }^{204} \mathrm{~Pb}$ & ${ }^{207} \mathrm{~Pb}$ & ${ }^{208} \mathrm{~Pb}$ & & ${ }^{207} \mathrm{~Pb} /$ & \\
\hline & 12 & & & & & & & & & \\
\hline L & 29.9 & 254. & & 36,000 & 1 & 18.446 & 6.774 & & 12 & 0.18420 \\
\hline & 19.2 & 526.7 & 268.6 & 24,166 & 0.001651 & 18.320 & 5.767 & 0.4777 & 12.054 & 0.18299 \\
\hline
\end{tabular}

All data except ${ }^{206} \mathrm{~Pb} /{ }^{204} \mathrm{~Pb}$ ratios were corrected for total $\mathrm{Pb}$ blanks of 7.2 (analysis $\mathrm{C}$ ) and 1.5 (analyses $\mathrm{A}$ and $\mathrm{B}$ ) nanograms. The blank $\mathrm{Pb}$ isotopic composition used was: ${ }^{206} \mathrm{~Pb} /{ }^{204} \mathrm{~Pb}=$ $17.46 ;{ }^{207} \mathrm{~Pb} /{ }^{204} \mathrm{~Pb}=15.25$; and ${ }^{208} \mathrm{~Pb} /{ }^{204} \mathrm{~Pb}=36.65$. The correction for common $\mathrm{Pb}$ amounted to less than 0.2 mole $\%$ with the assumed isotopic composition of ${ }^{206} \mathrm{~Pb} / 204 \mathrm{~Pb}=14.85$; ${ }^{207} \mathrm{~Pb} /{ }^{204} \mathrm{~Pb}=15.25 ;{ }^{208} \mathrm{~Pb} / 204 \mathrm{~Pb}=34.38$. 




Fig. 6. Analyses of the three zircon fractions from gabbro-anorthosite listed in table 5 plotted on a concordia diagram. Plotted precision errors are $\pm 0.7 \%$ (fractions $B$ and $C$ ) and $\pm 1.0 \%$ (fraction $\mathrm{A}$ ) for the $\mathrm{U} / \mathrm{Pb}$ ratios, and $\pm 0.1 \%$ (fractions $\mathrm{B}$ and $\mathrm{C}$ ) and $\pm 0.5 \%$ (fraction $\mathrm{A}$ ) for the ${ }^{207} \mathrm{~Pb} /{ }^{206} \mathrm{~Pb}$ ratios. The dashed line is the best fit line to fractions $\mathrm{A}$ and $\mathrm{C}$ which passes through the origin of the concordia diagram.

Constants used are: ${ }^{238} \mathrm{U} /{ }^{235} \mathrm{U}=137.88, \lambda(238)=1.55125 \times 10^{-10} \mathrm{yr}^{-1}, \lambda(235)=9.84850 \times$ $10^{-10} \mathrm{yr}^{-1}$ (Jaffey et al., 1971).

stants of Jaffey et al. (1971) are used. The errors for the intercept ages are estimated by constructing the extreme lines through all error polygons. Due to the near-concordance of the data, an upper concordia intercept age derived from a continuous $\mathrm{Pb}$ diffusion model (Tilton, 1960; Wasserburg, 1963) would not differ beyond the limits of error from the above result. It should be noted that if the uranium isotopic composition and the decay constants recommended by Stieff et al. (1959) were used an upper concordia intercept age of $2739 \mathrm{~m} . \mathrm{y}$. and a lower concordia intercept age of $470 \mathrm{~m} . \mathrm{y}$. would result. If the lower intercept age of 420-470 m.y. has any significance at all, it may reflect an episodic event such as metamorphism or leaching related to the late Caledonian orogeny. Because no geological evidence for a Caledonian metamorphic event in the sampling area 
investigated has yet been discovered, $\mathrm{Pb}$ loss by continuous diffusion may be a better explanation of the zircon discordance.

\section{Interpretation of results}

The $2700 \mathrm{~m}$.y age obtained further confirms the existence of an important thermal event dated by a variety of methods in the Archaean rocks of the North Atlantic craton between 2650 m.y. and 2900 m.y. ago (see for example Moorbath et al., 1969; Black et al., 1973; Evenson et al. quoted by Bridgwater, 1973; Lyon et al., 1972; Gulson \& Krogh, 1972; Turner, 1970). Whether the age obtained from the gabbro-anorthosite zircons represents the original crystallisation of these rocks or whether it represents a regional metamorphic event which has reset both the zircons in these particular specimens and a variety of mineral and whole rock systems over a large part of the Archaean block of Greenland, Labrador and North-West Scotland, is subject to debate.

Geologically, the main reason against accepting the age of $2700 \mathrm{~m} . \mathrm{y}$. as the age of the original crystallisation is that all the anorthosites of this type throughout the Archaean of West Greenland have been shown to be older than a 2800 m.y. metamorphic event while some of them can be shown to pre-date $3100 \mathrm{~m}$.y. granites. They occupy a similar position in the local succession of events recorded from South-East Greenland (Bridgwater et al., $1973 \mathrm{~b}$ ). If $2700 \mathrm{~m} . \mathrm{y}$. is accepted as their date of intrusion then this implies (1) that a large number of events regarded as having occurred after the emplacement of these particular gabbro-anorthosites are younger than $2700 \mathrm{~m} . \mathrm{y}$., or (2) that these events are all part of a single cycle, or (3) that the interpretation of the anorthosites as having been intruded early in the local sequence of events is incorrect. In any of these cases a considerable readjustment of the geological model previously presented (Bridgwater et al., $1973 \mathrm{a}, \mathrm{b}$ ) is required.

It has been suggested by Bridgwater et al. (1974) that anorthosites of this type were emplaced into the Archaean gneiss complex during active thrust movements. If the 2700 m.y. age is accepted as the age of intrusion of the Kitak bodies then it is possible that their intrusion together with the granites which break them up took place during the first thrust movements marking the formation of the Nagssugtoqidian mobile belt in South-East Greenland.

Most geochronologists think that the zircon system is the most valuable single tool for recording very old ages in rocks with complex geological histories (see for example: Goldich et al., 1970; Hart et al., 1968; Steiger \& Wasserburg, 1969; Nunes \& Tilton, 1971). An example of paragneiss zircons from the Alps which yielded apparently completely 'reset' ages due to metamorphism and granitisation, was recently reported by Koeppel \& Gruenenfelder (1971). In this case, however, the authors presented morphological and microprobe trace element evidence that they were analysing 'new' crystals which grew during the orogenic 
episode rather than pre-existing ('reset') zircons which lost all their lead at that time. In general, however, we would interpret a near-concordant zircon age from an igneous rock which still retained part of its original texture and suffered no more than amphibolite-grade metamorphism, as the age of the original crystallisation of the rock.

Recent zircon studies employing the 'teflon bomb' technique, may have revealed a sensitive test for the discrimination between metamorphic and intrusive ages. Apparently very small fractions of zircons with extreme physical properties do not fall on the line defined by the less extreme zirzon fractions if the rock has been subject to metamorphism. In such cases the coarse, least magnetic fraction usually plots below the best fit line, i.e. it shows an older ${ }^{207} \mathrm{~Pb} /{ }^{206} \mathrm{~Pb}$ age than the majority of the zircons (Krogh, pers. comm. 1972; Steiger et al., 1973; Oberli \& Steiger, 1973). We believe that this particular fraction is least vulnerable to disturbance due to its low radioactivity (low radiation damage) and large grain size, and is consequently best suited to retain a record of the earliest events measurable in any given suite of zircons.

A straight line (not shown on fig. 6) drawn through the centre of the error polygons for fractions $\mathrm{A}$ and $\mathrm{C}$ of the gabbro-anorthosite would pass above fraction $\mathrm{B}$ and crosses the abscissa to the right of the origin of the concordia diagram. As the latter is not possible for non-fractionating $\mathrm{Pb}$ loss, we must assume a minor inconsistency - though within limits of error - for our analytical data.

If we draw a best fit line through the data points for fractions $\mathrm{A}$ and $\mathrm{C}$ which also passes through the origin of the concordia diagram (dashed line in fig. 6), we recognise that the coarse, least magnetic fraction B still plots below this line. Fraction B which represents about $2 \%$ of the total zircon yield of the gabbroanorthosite, possibly retains a faint memory of a pre- 2700 m.y. event. Comparison with the work by Oberli \& Steiger (1973) and Steiger et al. (1973) suggests that high grade anatexis which involves the melting of mafic components (diatexis) is needed to reset the zircon clock to such a degree.

In summary, a $2700 \mathrm{~m} . \mathrm{y}$. old event has been documented by age determinations on zircons from gabbro-anorthositic inclusions in the gneisses of the Angmagssalik area. At this stage it is not clear, whether this age represents a massive metamorphic episode of a possibly very much older anorthosite or the crystallisation of the anorthosite itself. The present data should therefore be regarded as an incentive to future investigations both in the field and the laboratory.

\section{Acknowledgments}

We wish to thank $\mathbf{K}$. Gormsen who was jointly responsible for collecting the sample. We are grateful to R. Vollmer, W. Wittwer and Isabel Ball for the careful mineral separation, and to Marie-Therese Bär for some of the analytical work. 


\section{References}

Black, L. P., Moorbath, S., Pankhurst, R. J. \& Windley, B. F. 1973: The ${ }^{207} \mathrm{~Pb} /{ }^{206} \mathrm{~Pb}$ whole rock age of the Archaean granulite facies metamorphic event in West Greenland. Nature phys. Sci. 244, 50-53.

Bondesen, E. \& Henriksen, N. 1965: On some pre-Cambrian metadolerites from the central Ivigtut region, SW Greenland. Bull. Grønlands geol. Unders. 52 (also Meddr Grønland 179,2) 42 pp.

Bridgwater, D. 1973: General compilation of isotopic work on rocks from Greenland. Rapp. Grønlands geol. Unders. 55, 51-60.

Bridgwater, D. \& Gormsen, K. 1969: Geological reconnaissance of the Precambrian rocks of south-east Greenland. Rapp. Grønlands geol. Unders. 19, 43-50.

Bridgwater, D., Escher, A. \& Watterson, J. 1973a: Tectonic displacements and thermal activity in two contrasting Proterozoic mobile belts from Greenland. Phil. Trans. R. Soc. Lond. A, 273, 513-533.

Bridgwater, D., Watson, J. \& Windley, B. F. 1973b: The Archaean craton of the North Atlantic region. Phil. Trans. R. Soc. Lond. A, 273, 493-512.

Bridgwater, D., McGregor, V. R. \& Myers, J. S. 1974: A horizontal tectonic regime in the Archaean of Greenland and its implications for early crustal thickening. Precambrian Research 1, 179-197.

Escher, A., Escher, J. C. \& Watterson, J. in press: The reorientation of the Kangâmiut dyke swarm, West Greenland. MS submitted to Can. J. Earth Sci. 1973.

Goldich, S. S., Hedge, C. E. \& Stern, T. W. 1970: Age of the Morton and Montevideo gneisses and related rocks, Southwestern Minnesota. Bull geol. Soc. Amer. 81, 3671-3696.

Gulson, B. L. \& Krogh, T. E. 1972: U/Pb zircon studies on the age and origin of posttectonic intrusions from South Greenland. Rapp. Grønlands geol. Unders. 45, 48-53.

Hart, S. R., Davis, G. L., Steiger, R. H. \& Tilton, G. R. 1968: A comparison of the isotopic mineral age variations and petrologic changes induced by contact metamorphism. In Hamilton, E. I. \& Farquhar, R. M. (edit.). Radiometric dating for geologists, 73-110, New York: Interscience Publishers.

Herd, R. K. 1972: The petrology of the sapphirine-bearing and associated rocks of the Fiskenaesset complex, West Greenland. Unpubl. Ph. D. thesis, University of London, England, 2 vol., $608 \mathrm{pp}$.

Jaffey, A. H., Flynn, L. E., Glendenin, W. C., Bentley, W. C. \& Essling, A. M. 1971: Precision measurement of half-lives and specific activities of U(235) and U(238). Phys. Rev. C. 4, 1889-1906.

Koeppel, V. \& Gruenenfelder, M. 1971: A study of inherited and newly formed zircons from paragneisses and granitised sediments of the Strona-Ceneri-zone (Southern Alps). Schweiz. miner. petrogr. Mitt. 51, 385-409.

Krogh, T. E. 1973: A low-contamination method for hydrothermal decomposition of zircon and extraction of $\mathrm{U}$ and $\mathrm{Pb}$ for isotopic age determinations. Geochim. cosmochim. Acta, 37, $485-494$.

Lyon, T. D. B., Pidgeon, T. R., Bowes, D. R. \& Hopgood, A. M. 1972: Geochronological investigation of the quartzo-feldspathic rocks of the Lewisian of Rona, Inner Hebrides. Newsletter geol. Soc. Lond. 1, 3-4.

Moorbath, S., Welke, H. \& Gale, N. H. 1969: The significance of lead isotope studies in ancient, high-grade metamorphic basement complexes as exemplified by the Lewisian rocks of North-West Scotland. Earth planet. Sci. Lett. 6, 245-256.

Moorbath, S., O'Nions, R. K., Pankhurst, R. J., Gale, N. H. \& McGregor, V. R. 1972: 
Further rubidium-strontium age determinations on the very early Precambrian rocks of the Godthaab district, West Greenland. Nature phys. Sci. 240, 78-82.

Myers, J. S. 1973: Igneous structures and textures in the Majorqap qâva outcrop of the Fiskenæsset anorthosite complex, Rapp. Grønlands geol. Unders. 51, 47-53.

Nunes, P. D. \& Tilton, G. R. 1971: Uranium-lead ages of minerals from the Stillwater igneous complex and associated rocks, Montana. Bull geol. Soc. Amer. 82, 2231-2250.

Oberli, F. \& Steiger, R. H. 1973: U-Pb systematics of zircons from a migmatite area. [Abstract] Fortsch. Miner. 50, 112-114.

Palmer, K. 1971: A comparative study of two gneiss areas: - the Suportoq region East Greenland and south Harris, Outer Hebrides, and their bearing on Precambrian crustal evolution. Unpubl. Ph. D. thesis, University of Birmingham, England.

Pankhurst, R. J., Moorbath, S. \& McGregor, V. R. 1973: Late event in the geological evolution of the Godthaab district, West Greenland. Nature phys. Sci. 243, 24-26.

Steiger, R. H. \& Wasserburg, G. J. 1969: Comparative U-Th-Pb systematics in $2.7 \times 10^{9}$ year plutons of different geologic histories. Geochim. cosmochim. Acta 33, 1213-1232.

Steiger, R. H., Bär, M. T. \& Büsch, W. 1973: The zircon age of an anatectic rock in the central Schwarzwald. [Abstract] Fortsch. Miner. 50, 131-132.

Stieff, L. R., Stern, T. W., Oshiro, S. \& Senftle, F. E. 1959: Tables for the calculation of lead isotope ages. Prof. Pap. U.S. geol. Surv. 334-A, 40 p.

Tilton, G. R. 1960: Volume diffusion as a mechanism for discordant lead ages. J. geophys. Res. 65, 2933-2945.

Turner, G. 1970: Thermal history of meteorites. In Runcorn, S. K. (edit.). Palaeogeophysics, 491-502. London \& New York: Academic Press.

Wager, L. R. \& Hamilton, E. I. 1964: Some radiometric rock ages and the problem of the southward continuation of the East Greenland Caledonian orogeny. Nature, Lond. 206, 1079-1080.

Wasserburg, G. J. 1963: Diffusion processes in lead-uranium systems. J. geophys. Res. 48: $4823-4846$.

Wetherill, G. W. 1956: Discordant uranium-lead ages, I. Trans. Amer. geophys. Un. 37, 320-326.

Windley, B. F., Herd, R. K. \& Bowden, A. A. 1973: The Fiskenæsset complex, West Greenland. Part I. A preliminary study of the stratigraphy, petrology, and whole rock chemistry from Qeqertarssuatsiaq. Bull. Grønlands geol. Unders. 106 (also Meddr Grønland 196,2) $80 \mathrm{pp}$.

*P. D. N. now at

United States Geological Survey,

Denver Federal Center,

Denver,

Colorado 80225 ,

U.S.A.
R. H.S. \& P.D.N.*

Institut für Kristallographie und Petrographie,

Eidg. Technische Hochschule, Sonneggstrasse 5 , 8006 Zürich, Switzerland. 